\title{
On Re-instantiation of Literary Dialects: A Systemic Functional Approach*
}

\author{
Jing Chen \\ Southwest Petroleum University, China
}

\begin{abstract}
With the developments in Systemic Functional Linguistics (SFL), the functional approach to translation studies (TS) has offered new perspective into understanding how translation can be viewed as the re-instantiation of Source Text (ST) in another language system as Target Text (TT).In literary texts, language variations such as literary dialects have long been considered challenges in translation, but literary dialects are also believed to be "valued" linguistic elements since non-standard language such as dialects are socially related and may trigger linguistic stereotypes among readers. In tune with the new development in SFL, the current research focuses on the English translations of dialects in Li Jieren's Si Shui Wei Lan (死水微澜) which is rich in Sichuan dialects and are with linguistically varied voices. The purpose of this article is threefold: firstly, to briefly present the linguistic features of ST, revealing author's intentional arrangement in his choices of dialects; secondly, with case studies to compare and discuss the translators' choices in re-instantiating dialects from the perspective of coupling and commitment; finally, to offer suggestions for translating literary dialects. This paper argues that SFL helps translators pinpoint the linguistic features that are valued in ST and inform translators of alternative renderings. This paper adopts a descriptive approach to the triplet on how translators re-coupled and re-committed the language variations in the ST into TT, and it serves as a manifestation of how SFL applies to TS from a new angel.
\end{abstract}

Index Terms - systemic functional linguistics, coupling and commitment, dialect translation, literary dialect, Language variation

\section{INTRODUCTION}

Systemic Functional Linguistics (SFL) has long been applied to Translation Studies (TS) (Catford, 1965; House 1981; Baker 1992; Hatim \& Mason 1990, 1997; Munday 1998). SFL sees language in use as a result of choice-making in systems where higher level systems are realized by lower level subsystems. A lot of efforts were put into locating and ensuring the metafunctional equivalent form of Source Text (ST), and Matthiessen (2001) noted that translation has been "modeled against the parameters of equivalence and shift" (p.87). Though long been a focus in TS, the term "equivalence" is problematic in the sense that there is hardly absolute and ideal equivalence between languages and as "we translate texts in one language into texts in another; but we do not translate one language into another language" (Matthiessen, 2001, p.87).

With the development of SFL, Martin $(2006,2008,2010)$ proposed another two hierarchies besides realisation: instantiation and individuation and argues that three hierarchies are complementary perspectives on language in context. He then goes on to utilize all three hierarchies in text analysis and concludes that three hierarchies have their own advantages. "Realisation is effective in showing where texts are similar and different", and "instantiation is better designed to explore how texts arise", while "individuation allows us to bring the interests of individuals and interest groups into the picture" (Martin, 2006, p.295). Matthiessen (2001) and Steiner (2001, 2005) also incorporate instantiation into TS by viewing translation as the studies on relationship between texts.

Halliday (2001) believes that "for a linguist, translation theory is the study of how things are: what is the nature of the translation process and the relation between texts in translation." (p.14). He suggests that "good translation" is the translation that preserve "those linguistic features which are most valued in the given translation context." (ibid. p.16) and SFL is helpful in locating these "valued" features and in informing translators' alternative choices. In literary texts, language variations seem to be a good example of "valued" linguistic elements. Authors' decision of prioritizing certain linguistic components contributes to the shaping of characters and achieving certain effects. As dialects are mostly social-related, the heavy social and ideological investments in a dialect are valuable when author intends to trigger readers' "feelings" or "stereotypes". However, in inter-lingual communication as translation, TT readers may not share the same knowledge regarding these perceived stereotypes, thus one big challenge for translator is to re-build similar link between linguistic variants and social-ideological information. Due to these difficulties, some consider the translation of accents and dialects impossible (House, 1973), but to translate dialects into standard language inevitably results in removal of linguistic variety and compromise ST's value. As noted by Halliday (2002), translators cannot translate dialects; all we can do is to mimic the variation in dialects. This, therefore, requires translators to first

\footnotetext{
* This paper is supported by Sichuan Social Science Research Project (Grant No. SC16WY034)
} 
recognize and analyze the relation and hierarchy between language variants in the text, and then re-present the hierarchy of variations in TT. However, little attention is given to the English translation of Chinese literary dialects, and even fewer studies are done concerning Sichuan dialects.

Thus this paper is an attempt of analyzing how dialects, and specifically Sichuan dialects, are represented in English from new functional perspectives. It adopts a descriptive approach to the novel, Si Shui Wei Lan(《死水微澜》), and its two English translations, aiming at revealing how translators re-instantiate the language variations in ST into TT through coupling and commitment, and it serves as a manifestation of how SFL applies to TS from a new angel.

\section{ANALYTICAL FRAMEWORK}

SFL provides theoretical basis for the following analysis. Translation, first of all, may be viewed as a re-instantiation of the ST, and coupling and commitment are useful analytical tools to understand relationship between texts. Thus they serve as the basis of analysis in this paper.

\section{A. Translation as Re-instantiation}

According to Halliday and Matthiessen (2004), instantiation is a cline from potential (language system) to instance (text), and at intermediate level is register and text type.

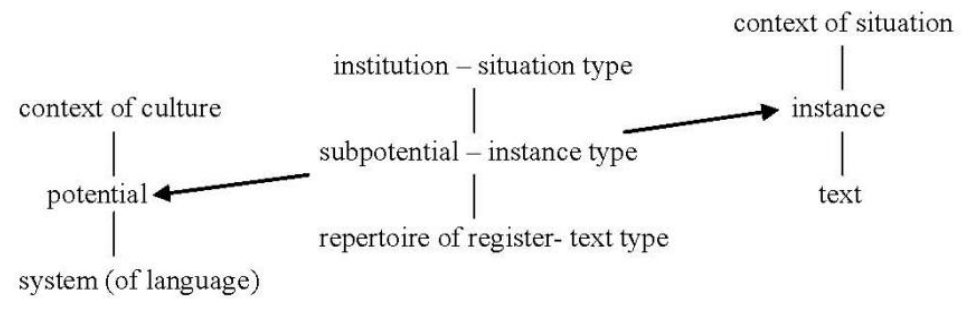

Figure 2 1: The cline of instantiation proposed by Halliday \& Matthiessen (2004, p.28)

Martin (2006) adds "reading" at the bottom level and distinguishes genre/ register and text type.

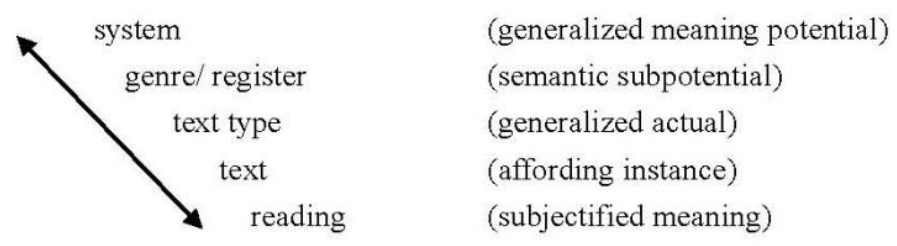

Figure 2 2: The cline of instantiation proposed by Martin (2006, p.285)

Martin's concept of "reading" is the "subjectified meaning" interpreted by individual readers of the instance. According to him, re-instantiation is the process by which one instance re-construes the meaning potential of a given source instance (Martin 2006). Translation firstly involves "distantiation", a "metaphorical process of reaching up the cline to recover meaning potential" (Martin, 2008, p.50) in Source Language (SL) system and then an "instantiation", moving back down the cline to the instance end to create TT. Translators' choices are influenced by their afford reading, the coupling and commitment available in Target Language (TL) system, and their individual repertoires.

In this paper the translation process is seen as an inter-lingual communication through translators' re-writing which in essence entails deliberate choices through the three hierarchies of realisation, instantiation and individuation. Translation is about how to re-instantiate the meaning potential in ST. In other words, in translation practice, a translator is both the reader of ST and writer of TT. When reading ST, s/he is moving upward along the cline, from the language instant to semantic and even genre level to obtain the meaning, which includes the literal as well as the semantic or metaphoric meaning. With this understanding, s/he then deploys the TL resources, his/her TL repertoire, to re-construe the meaning potential with another language. For this reason, translation is about how ST source out and re-instantiate in another language.

\section{B. Coupling and Commitment}

Coupling and commitment are introduced by Martin as tools to explore the relationship between system and texts. Coupling describes the dynamic process of combining choices across strata/rank or systems; it is "the ways in which meanings combine, as pairs, triplets, quadruplets or any number of coordinate choices from system networks" (Martin, 2008, p.39). Coupling may indicate combined choices in higher level or lower as lexico-grammatical level. For example, complaints would be coupled with unfavorable choice of diction that implies attitude or judgment. Coupling happens at higher level as well. As a translator moves back to the instance end, trying to rewrite TT, s/he has to consider the genre, text type, existing TL texts with similar text type and what that certain text type requires as its default setting. To render texts to suit such social expectations is to make choices in the system with coupling. In this sense, translators are 
constantly re-coupling in TL when translating.

Commitment is "the degree of specificity of the meaning instantiated in a text" (Martin, 2010, p.20). It can be shown from two aspects: number of events and level of specificity. The more events, more delicate or specific the meaning the more committed the text is. In translation, TT generally shares the meaning potential of ST but ST may very often be more or less committed than TT, thus analysis and comparison of the re-commitment of TT is actually the investigation in semantic relations between texts. Especially when there is more than one translation of one source instance, the choices translators made might demonstrate different level of re-commitment. Martin (2008) analyzed a triplet of a same story of a girl and revealed different degree of commitment in three texts. "The driver" is more committed than "a man"; "ran through the bush" is more committed than "going away". Translators' standpoints and decisions are reflected by different degrees of commitment in TTs.

\section{LINGUISTIC VARIETIES IN SI SHUI WEI LAN}

Si Shui Wei Lan is written by modern Sichuan writer Li Jieren (1891-1962). It was written in 1935 and first published in 1955. It is the first novel in the "River Trilogy" of Li Jieren based on social life in Sichuan in the turn of the $20^{\text {th }}$ century. Two chapters of this novel were translated into English and published on the $11^{\text {th }}$ and $12^{\text {th }}$ issue of Chinese Literature in 1981. The translator is Hu Zhihui (some argues that the translator is Gladys Yang). Then in 1990, as one of Panda Books, Ripples across Stagnant Water was introduced to English world by Chinese Literature Press. In 2014 MerwinAsia published a new English version of this novel with the title Ripple on Stagnant Water: A Novel of Sichuan in the Age of Treaty Ports and translators are Bret Sparling and Yin Chi.

This novel is set against the backdrop of Chinese society after Sino-Japanese War of 1894-1895. With characters from different social backgrounds and their stories in a small rural village called Tianhui Zhen (天回镇) and in Chengdu, Ripples across Stagnant Water vividly depicts people's life in Chengdu towards the end of the Qing Dynasty and how small characters' personal lives are influenced by the historic events and forces. The protagonist is Litter Sister Deng, who later married a restaurant owner Cai and is referred to as Cai's wife. In the cultural background of women deference which is highly emphasized in China at that time, the female protagonist's story is one of courageous pursuit of happiness, and self-awakening. Hence, one Chinese writer Guo Ruomo commented Li Jieren as Emile Zola of China. One prominent feature of Si Shui Wei Lan is heavy use of Sichuan dialects. The language in the novel is linguistically varied.

The use of dialect in this novel is carefully arranged by the author. The narration part of the novel is "quasi standard language" which employs some dialectic expressions, while the grammar and overall structure is still literary. There is also use of Classical Chinese in the novel when the protagonist is reading an article. Dialects are absent in such cases, which the grammatical forms and sentence patterns comply with the rules in written Classical Chinese. Characters from various social levels are also associated with different level of dialect use. for instance, Deng Dasao (邓大嫂) is an uneducated woman from Tianhui. Her language is vulgar and dialectic. Luo Waizui (罗歪嘴) is literate but joins Gelaohui (袍哥), a fraternity of the underworld, thus his language is featured by dialects and idioms. Deng Yaogu (邓乡 姑) is a beautiful and sophisticated country woman yearning for everything in the city. There are dialects in her utterances but the grammar and structure are close to that of the city ladies, and the language of Second Mistress Han (韩二奶奶), a lady from the city is with only light touch of local color as her language is quite close to standard language. The use of vernacular languages in Li' novel is hardly random; there is a hierarchy of linguistic variety which differentiates characters thus reminding of the speaker's different social background.

\section{CASE STUDY: Re-INSTANTIATION OF DiALECTS}

In order to reveal how different translators instantiated dialects, analysis is conducted from functional perspective, with emphasis on coupling and commitment.

For the following analysis, examples from the original text are marked as ST and the 1990 translation version is labeled as TT1, 2014 version as TT2 in the table below. The highlighted parts are dialects and their translations, and underlined part in bold are examples of translators' different choices in commitment. 
TABLE II.

EXAMPLES OF DIALECT TRANSLATION FROM ST, TT1 AND TT2

\begin{tabular}{|c|c|c|c|}
\hline & ST & TT1 & TT2 \\
\hline $\begin{array}{l}\text { Example } \\
1\end{array}$ & $\begin{array}{l}\text { 她 (邓大嫂) 说: “怕在沟边上罢? 那娃 } \\
\text { 儿光爱跑那些地方的。” } \\
\text { (cf: 第一部分 序幕) }\end{array}$ & $\begin{array}{l}\text { She said: "Isn't he by the } \\
\text { brook? That's where he likes } \\
\text { to play." }\end{array}$ & $\begin{array}{l}\text { "Out by the canal, I suppose," she } \\
\text { told us. "That bairn does nothing } \\
\text { but run off to those places." }\end{array}$ \\
\hline $\begin{array}{l}\text { Example } \\
2\end{array}$ & $\begin{array}{l}\text { (陆茂林说) “放你的屁！你谅实老子蚀 } \\
\text { 不起吗？” } \\
\\
\text { (cf: 第三部分 交流 1) }\end{array}$ & $\begin{array}{l}\text { "You're farting! Think I can't } \\
\text { pay?" }\end{array}$ & $\begin{array}{l}\text { "Go on with your farts!" cursed } \\
\text { Shaggy Lu. "You think your liege } \\
\text { can't pay?" }\end{array}$ \\
\hline $\begin{array}{l}\text { Example } \\
3\end{array}$ & $\begin{array}{l}\text { 他 (顾天成) 的回答才是: “你还问呢? } \\
\text { 我就是吃死了这两个人的亏了! 没有他 } \\
\text { 们, 我的几十亩地方, 就凭我脾气出脱, } \\
\text { 也不会像这几天这样快呀! 闹棂果, 还 } \\
\text { 遭一个婊子欺负, 挨了这一顿! ” } \\
\text { (cf: 第三部分 交流 7) }\end{array}$ & $\begin{array}{l}\text { So he said: "Why ask? It is } \\
\text { their fault that I'm in trouble. } \\
\text { If not for them I wouldn't } \\
\text { have lost all my land in the } \\
\text { last few days, could have } \\
\text { sold it to suit myself. I got } \\
\text { tricked by a dirty prostitute } \\
\text { and beaten up ..." }\end{array}$ & $\begin{array}{l}\text { So his retort to his wife was: } \\
\text { "Funny you should ask about my } \\
\text { uncles. It's exactly those two that } \\
\text { forced this grief down my throat. } \\
\text { If it weren't for them, those } \\
\text { dozens of mu of mine, however } \\
\text { bad I lost my head, they never } \\
\text { could have gone as fast as that. } \\
\text { And then in the end to get played } \\
\text { by a filthy whore and beaten up } \\
\text { like this ---!" }\end{array}$ \\
\hline $\begin{array}{l}\text { Example } \\
4\end{array}$ & 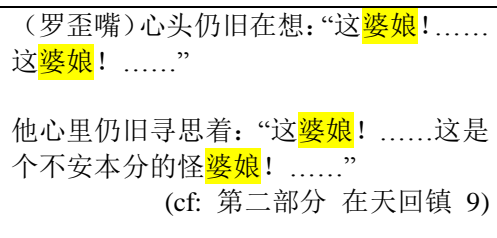 & $\begin{array}{l}\text { He was thinking: "What a } \\
\text { woman! ..." } \\
\text { Again he thought: "What a } \\
\text { strange woman ... not } \\
\text { contented with her lot in } \\
\text { life..." }\end{array}$ & $\begin{array}{l}\text { What was going on through his } \\
\text { mind was: "The wench! ...Oh the } \\
\text { wench!..." } \\
\text { "Oh, the wench!" he inwardly } \\
\text { groaned. "The bewitching wench } \\
\text { that don't keep to her station!" }\end{array}$ \\
\hline
\end{tabular}

From examples in the above table, it is not difficult to find that though most are preserved in TT, dialects are handled differently.

\section{A. Coupling in Dialect Translation}

Coupling is a dynamic process constantly happening in translating. Example 1,2 and 3 are good demonstrations. Example 1 is uttered by Deng Dasao, an uneducated old lady from the countryside; therefore her utterance is characterized by a dense use of Sichuan dialect. "怕” in ST is a case in point. It usually comes before clause and means "perhaps", "I'm afraid" or "I think". “罢” is an imitation of the accent of Sichuan dialect. It frequently appears at the end of the clause. Together with “怕” the structure indicates personal speculation. “娃儿” which means kid or lad, suggests higher status of the speaker and “光爱” in Sichuan dialect literally means "just love to" or "only like to". ST is ended with a question mark but actually is a statement, which indicates it is an interpersonal grammatical metaphor. TT1 keeps the interpersonal grammatical metaphor thus is the congruent form to ST but does not represent the dialectic elements. In TT2 Sparling renders it into a statement and uses "I suppose" to represent the meaning of the dialect “怕” and “罢”. For the second clause, TT1 changes Theme-Rheme structure into a marked thematic equative of "That is where" and simplifies the dialect into "he". TT2 represents the same thematic structure, and it re-instantiate the dialect by translating it into "that bairn" instead of "that boy", which is also further down the delicacy line thus more committed. For cases like this, it is wise to be mindful of the linguistic features in ST since Deng Dasao's discourse is loaded with dialects which vividly depicts her characteristics and her social status, and this is also why her utterances are also short clauses. For this reason, TT2 is better in the sense that it reproduces the omission in the first clause, mimicking the feature of oral language, and respects the thematic structure and dialect in the second clause, on the other hand, TT1 blurs the linguistic features and reconstructs the thematic structure with a more complicated structure, though this creates smoother information progression between two clauses, it is contradictory to the speaker's status. TT2 may be viewed as a good example of representing Deng Dasao's speech features and social status by coupling words with clause and grammatical metaphor.

The same is true for example 2 and 3, which are cases with obvious results of coupling. ST in Example 2 shows the gross language of Lu Maolin, who loves gambling and visiting brothel. “老子” is a vulgar term which literally means father or aunt from the father's side. It is normally used to indicate contempt or provocation in casual conversations. “谅 实” means thinking in a disproving way. “蚀” is an imitation of the accent of the word "eat" in Chengdu dialect. TT2's translators are more aware of such linguistic variety in ST. They consciously choose Shaggy Lu to name Lu Maolin, and add "cursed" to couple Lu's behavior, which is more committed than "said". Especially with the translation of “老子", TT2 uses "liege" to indicate higher status and preserve the time identifier with old-fashioned word, but TT1 uses a more general term "I" which removes the vulgarity and compromise the information attached. In TT2, dialects and vulgar language are coupled by these unfavorable choices of words like "shaggy" and "curse" which are actually absent in ST. The purpose of such creative translation is to rebuild this character through coupling. However, TT1's translator is more prudent. He translates 陆茂林 into Lu Maolin or Lu and he dismisses some dialects in his dialogue. Hu's choices 
ultimately lead to standardization of character's discourse.

In Example 3, after being tricked by a prostitute and some gamblers Gu goes back home in fury to complain to his wife about his experience. His utterances are coupled with negative structures and judgments like “吃死了...... 亏”, “出 脱”, “闹整果”, “遭”, “婊子”, “欺负” and “挨”. “整果” imitates the pronunciation of “the end” in Sichuan dialect and “闹” indicates the ridiculous and outrageous experience the speaker has had. “出脱” suggests something is gone in an extravagant and often pitiful fashion. In TT1, Hu uses "fault", "lost", "got tricked", "dirty prostitute" to demonstrate Gu's anger. Similarly, in TT2, "force down", "grief", "bad", "lost", "gone", "in the end", "get played" and "filthy whore" are employed to reinforce Gu's emotion. TT1 does not preserve the dialect “闹鞄果” and mistranslate “出脱” into sell. TT2 keeps the dialects and deploys more lexical features to better couple speaker's feeling, and in TT2 Gu made a "retort" to his wife who is showing concerns. The diction is more committed than "said" in TT1. From these examples, it is noteworthy that when it seems impossible to find equivalent to some dialectic elements, translators may consider rewrite similar linguistic features and hierarchies through coupling and coupling may serve as an efficient way to represent the features and realize the effect of dialects in the ST.

\section{B. Commitment in Dialect Translation}

Commitment concerns the delicacy of meaning. Example 4 in the table 2 is a good example. “婆娘” in Sichuan dialect means wife or woman, usually associated with intimacy or unfavorable feelings. In ST, this clause is what Luo Waizui thought to himself when he for the first time yields to his attraction to his cousin's wife. Semantically, "wench" is more committed than "woman" as it is further down the delicacy line, thus is closer to the dialect in ST. TT2 also preserves the repetition in ST and adds "Oh" and uses a more committed "groan" to highlight character's affection.

TABLE III.

DEGREE OF COMMITMENT IN ST, TT1 AND TT2

\begin{tabular}{|c|c|c|}
\hline ST & TT1 & TT2 \\
\hline $\begin{array}{l}\text { (罗歪嘴) 心头仍旧在想: “这婆 } \\
\text { 娘！......这婆娘！......” } \\
\text { 他心里仍旧寻思着: “这婆娘！.......这 } \\
\text { 是个不安本分的怪婆娘！......” } \\
\text { (cf: 第二部分 在天回镇 9) }\end{array}$ & $\begin{array}{l}\text { He was thinking: "What a woman! ..." } \\
\text { Again he thought: "What a strange } \\
\underline{\text { woman }} . . . \text { not contented with her lot in } \\
\underline{\text { life ..." }}\end{array}$ & $\begin{array}{l}\text { What was going on through his mind } \\
\text { was: "The wench! ...Oh the wench!..." } \\
\text { "Oh, the wench!" he inwardly groaned. } \\
\text { "The bewitching wench that don't keep } \\
\text { to her station!" }\end{array}$ \\
\hline $\begin{array}{l}2 \text { specifications of process } \\
4 \text { specifications of entities }\end{array}$ & $\begin{array}{l}2 \text { specifications of process } \\
3 \text { specifications of entities }\end{array}$ & $\begin{array}{l}2 \text { specifications of process } \\
5 \text { specifications of entities }\end{array}$ \\
\hline
\end{tabular}

If we mark the specifications of process and entities in ST and two TTs, we may find that TT2 uses more specifications and is more committed than TT1. TT2 re-instantiates the dialects in ST with more committed choices and offers a better representation of the tide of emotion of the character.

\section{Discussion}

There are more examples in the novel but as examples from TT2 demonstrate, the 2014 version is bolder in translating Sichuan dialects in the novel from the perspective of coupling and commitment. The translators utilized more linguistic features to represent the dialects, and for better re-instantiation of characters, especially those whose use of dialect reflect their social status or personalities, coupling is used with committed words, phrases, clauses and structures. Generally speaking, the 2014 translation is the version with better re-instantiation of the original with the help of coupling and commitment. Of course, the 1990 translation should be read against the backdrop the $20^{\text {th }}$ century when translation of Chinese literary dialects was still in the bud, and at that time foreigner's interests and acceptance of translated Chinese novels are quite limited. But recent decades have witnessed growing interests in and number of translated Chinese works. It seems advisable for current translators to first be fully aware of the roles of dialects in the works they are translating and be open to the possibilities of translation offered by coupling and commitment. Therefore, SFL may well serve as a tool for text analysis to reveal meaning of dialects and instantiation in SFL could offer a new perspective in representation of literary dialects.

\section{CONCLUSION}

SFL has proved to be a useful tool in analyzing texts and bringing hidden meanings to light. To see translation from the new systemic functional angel is believed to be helpful in pinpointing the valued and prominent features in ST and informing translators of alternative renderings. The current research adopts a descriptive approach to compare the translations of dialects in Li Jieren's novel Si Shui Wei Lan through the lens of coupling and commitment.

Through case study it is found that ST is featured with linguistic variety in its use of dialects. Different investment in dialects indicates the author's conscious arrangement. When translating literary dialects, it is suggested that the first step is to analyze ST and distinguish prominent linguistic elements from others. In translating language variations, congruent form is not always better than metaphoric expression. The acid test is whether there is any additional meaning intended when author chooses this form other than that. If author's decision is intentional, it is wise to represent congruent 
functional structure to ensure similar effects. When language variants are involved, it is not always possible to find equivalent in TL; especially when such socio-cultural-related expression is absent in TL, translators might consider looking for alternatives through coupling and commitment. If translators can rewrite TT in the way that reflects similar linguistic hierarchy as ST, TL readers can better decode and re-construe the meaning as SL readers do.

Due to the limited space, the analysis in paper is far from thorough and more analysis could be done from the individuation hierarchy to reveal translators' intentional or unintentional choices. In addition, since the two English translations are twenty years apart from each other and rendered by translators from different backgrounds, discussion on their different translating strategies may be fruitful for future introduction and promotion of Chinese literary dialect.

\section{REFERENCES}

[1] Baker, M. (1992). In other words - A coursebook on translation. London: Routledge.

[2] Catford, J. C. (1965). A linguistic theory of translation. London: Oxford University Press.

[3] Halliday, M. A. K. (1985). An introduction to functional grammar. London: Edward Arnold.

[4] Halliday, M. A. K. (2001). Towards a theory of good translation. In E. Steiner \& C. Yallop (Eds.) Exploring translation and multilingual text production: Beyond content. Berlin/ New York: Mouton de Gruyter, 13-18.

[5] Halliday, M. A. K. (2002). Linguistic studies of text and discourse. London: Continuum.

[6] Halliday, M. A. K. (2010). Pinpointing the choice: Meaning and the search for equivalents in a translated text. In A. Mahboob \& N. Knight (Eds.), Applicable linguistics: Texts, contexts and meanings. London: Continuum, 13-24.

[7] Halliday, M. A. K. \& Matthiessen, C. (2004). An introduction to functional grammar ( ${ }^{\text {rd }}$ edn.). London: Arnold.

[8] Hatim, B. \& Mason, I. (1990). Discourse and the translator. London: Longman.

[9] Hatim, B. \& Mason, I. (1997). The translator as communicator. London: Routledge.

[10] House, J. (1981). A model for translation quality assessment ( $2^{\text {nd }}$ edn.). Tubingen: Gunter Narr.

[11] Li, Jieren. (1990). Ripples across stagnant water. Beijing: Chinese Literature Press.

[12] Li, Jieren. (2000). Si Shui Wei Lan. Beijing: Chinese Literature Press.

[13] Li, Jieren. (2014). Ripple on stagnant water: A novel of Sichuan in the age of treaty ports. Portland: Merwin Asia.

[14] Martin, J. R. (2006). Genre, ideology and intertextuality: A systemic functional perspective. Linguistics and Human Science, 2, 275-298.

[15] Martin, J. R. 2008. Tenderness: Realisation, instantiation and individuation in a Botswanan town. In N. Norgaard (Ed.), Systemic functional linguistics in use. Odense: Odense Working Papers in Language and Communication, 29, 30-62.

[16] Martin, J. R. (2010). Semantic variation: Modelling system, text and affiliation in social semiosis. In M. Bednarek \& J. R. Martin (Eds.), New discourse on language: Functional perspectives on multimodality, identity and affiliation. London/ New Work: Continuum, 1-34.

[17] [Matthiessen, C. (2001). The environments of translation. In E. Steiner \& C. Yallop (Eds.), Exploring translation and multilingual text production: Beyond content. Berlin/ New York: Mouton de Gruyter, 41-124.

[18] Munday, J. (1998). A computer-assisted approach to the analysis of translation shifts. META, 43, 52-56.

[19] Steiner, E. (2001). Intralingual and interlingual versions of a text - How specific is the notion of translation? In E. Steiner \& C. Yallop (Eds.), Exploring translation and multilingual text production: Beyond content. Berlin/ New York: Mouton de Gruyter, 161-190.

[20] Steiner, E. (2005). Some properties of texts in terms of information distribution across language. Languages in Contrast, 5 , 49-72.

[21] Thompson, G. (2004). Introducing functional grammar ( $2^{\text {nd }}$ edn.). London: Arnold.

Jing Chen was born in Zigong, Sichuan, China in 1984. She received her Master's degree in applied linguistics from Sun Yat-sen University, China in 2008.

She is currently a lecturer in the School of Foreign Languages, Southwest Petroleum University, Chengdu, China. She was on Fulbright FLTA program from 2014-2015 and published The Belt and Road in national and international news (Beijing: Petroleum Industry Press, 2018). Her research interests include systemic functional linguistics, translation and discourse analysis. 